\title{
AGRICULTURAL LAND AND LAND TAX - SIGNIFICANT INDICATORS OF AGRICULTURE BUSINESS ACTIVITIES IN THE SLOVAK REPUBLIC
}

\author{
Renáta Krajčírová, Alexandra Ferenczi Vaňová1, Michal Munk²
}

Received 18 February 2016; Accepted 30 June 2016

\begin{abstract}
The article is focused on the consideration between the agricultural land acreage and the amount of land tax in the selected sample of companies of agricultural primary production in the Slovak Republic within the period from 2010 to 2014 based on the data from departmental database of enterprises with primary agricultural production drawn from the factsheets of Ministry of Agriculture and Rural Development of the Slovak Republic presented by the selected statistical methods. In particular, the article presents the agricultural land and land tax from the accounting and tax perspective of the Slovak Republic and the European Union. It can be resulted that a slightly declining trend of the mean acreage of agricultural land was recorded for the evaluated group of agricultural enterprises within the reported period, while the mean land tax value per hectare of agricultural land had increasing trend. Results of the survey on significances of differences in the values of the dependent variables at the level of combinations of factors of year and enterprise indicate that the acreage of agricultural land and the volume of the land tax are statistically dependant at the level of year, however there are not dependent at the level of combination of factors of year and enterprise within the surveyed period.
\end{abstract}

Key words: agricultural land, land tax, asset, Slovak Republic

\begin{abstract}
Abstrakt: Príspevok je zameraný na posúdenie výmery pol'nohospodárskej pôdy a výšky dane $z$ pozemkov $v$ hodnotenom súbore pol'nohospodárskych podnikov $v$ SR v sledovanom období rokov 2010 až 2014, a to na základe údajov získaných z Informačných listov MPRV SR prostredníctvom vybraných štatistických metód. Zároveň sa príspevok zaoberá pol'nohospodárskou pôdou a daňou z pozemkov z hl'adiska účtovnej a daňovej legislatívy Slovenskej republiky a legislatívy EÚ. Na základe dosiahnutých výsledkov, priemerná výmera pol'nohospodárskej pôdy vo výberovom súbore podnikov $v$ hodnotených rokoch zaznamenala trend mierneho poklesu, pričom priemerná daň z pozemkov prepočítaná na 1 hektár pol'nohospodárskej pôdy dosiahla rastúci trend. Z testovania významnosti rozdielov
\end{abstract}

\footnotetext{
1 Ing. Renáta Krajčírová, PhD., Ing. Alexandra Ferenczi Vaňová, PhD., Slovak University of Agriculture in Nitra, Faculty of Economics and Management, Department of Accounting, 94976 Nitra, Tr. A. Hlinku 2, Slovak Republic; emails: renata.krajcirova@uniag.sk; alexandra.ferenczi@uniag.sk

2 doc. RNDr. Michal Munk, PhD.,Constantine the Philosopher University in Nitra, Faculty of Natural Sciences, Department of Informatics, 94974 Nitra, Tr. A. Hlinku 1, Slovak Republic; e-mail: mmunk@ukf.sk
} 
v hodnotách vybraných premenných podla kombinácií úrovni rok a podnik vyplýva, že výmera pol'nohospodárskej pôdy a výška dane z pozemkov sú závislé na úrovni faktora rok, ale nie sú závislé na úrovni kombinácií faktorov rok a podnik.

Klúčové slová: pol'nohospodárska pôda, daň z pozemkov, majetok, Slovenská republika

\section{Theoretical introduction}

The United Nations Organization has declared the year 2015 as the International Year of Soils. Land is usually a limited resource; therefore the soil protection is inevitable.

Landscape is one of the most commonly cited elements of the multifunctional characteristics of the agricultural sector (Cahill, 2001). Rural areas still cover $90 \%$ of the EU territory, of which more than half is farmed (Loudjani, Devos, 2012). The size of every farm is always relative in relation to the distribution of the whole agricultural land in every country between particular companies.

One of the basic features of agricultural production is that land is an active determinant of the reproductive process; it is the basic means of production. In most other industries, land is only a space where the reproductive process takes place, and therefore, as a rule, its quality does not affect the process. Land quality is an important factor for the entire reproductive process in agriculture (Sivák et al., 2015).

Agricultural land represents the basic economic resource in the agricultural sector and thus it is classified as one of the three basic production factors of market economy. Land does not reproduce, it is not transferable and its total extent is determined by the area that can be integrated into the agricultural production (Bielik, Turčeková, 2013).

Land and resource policy is the key to the future economic and social development. Land tenure also plays a vital role in achieving sustainable rural development (Schwarcz et al., 2013).

The emphasis is set on agricultural land of small farms as well as large agricultural companies and its crucial task is to determine the rural health economy and the creation of rural country (Králiková et al., 2013).

Creation and development of a favourable business environment in regions is unthinkable without an appropriate tax system. Creating a tax system, each country has to consider not only the increased revenue collection from taxpayers, but it also has to be able to develop the business environment and to promote the people's prosperity by reducing differences in the regional development (Puzule, 2015).

Several studies document that the land markets in the transition countries, even among the most advanced such as those in Central Europe, were characterized by the existence of substantial transaction costs in rural land markets (Dale and Baldwin, 2000; Lerman et al., 2004).

Entrepreneurship involving agricultural land belongs among the oldest economic sectors of every country. Slovakia and its countryside have been a typical agrarian country for many centuries. Despite the whole-area industrialization, which took place after 1950, agriculture remained as a characteristic feature of its countryside. Sectoral organization of agricultural production was evidentially created as a result of manufacturing expansion. It was caused by the industrialization process. It led to a largely one-sided orientation of rural regions towards agricultural activities. In the current era of globalization, especially after the accession to the EU, the position of agriculture is changing, especially in the trend of the EU Common Agricultural Policy reforms (Horská et al., 2013).

The current status of the land resources management in Slovakia is characterised by an extremely fragmented land ownership, as well as the size of the utilized agricultural land in large farms (cooperatives, business companies) and self-employed farmers. Only a few landowners utilize land for the business purposes. Most of the landowners lease their land (Bandlerová et al., 2015). Land consolidation represents an important instrument of rural 
development for agribusinesses as a tool for clarification of ownerships and as a remedy to the needs of the landscape (Podhrázská et al., 2015).

Taxes have the greatest influence on the market when the tax regulations are changed. At other times, taxes are a stable factor. However, taxes can have significant influence at the regional level, for example land taxes imposed by municipalities can vary considerably between areas or regions. Land taxes are an important source of government revenue. Income from these taxes also ensures that a proper land registration system can be maintained and that there is a sound institutional framework for the defence of secured property rights (Land in Europe: Prices, Taxes and Use Patterns, 2010).

\section{Methodology and Data}

The article deals with evaluation of the agricultural land's acreage and the amount of the land tax in selected sample of enterprises with primary agricultural production in the Slovak Republic from 2010 until 2014. Data sources represent the data from departmental database of enterprises with primary agricultural production drawn from the Information Letters of Ministry of Agriculture and Rural Development of the Slovak Republic (hereinafter referred to as "MARD."), which include the data from financial statements of individual enterprises, i.e. from the balance sheet, the profit and loss account and the notes.

The sample includes only those enterprises with primary agricultural production, whose existence is conditional on the implementation of business activity during the reporting period and, at the same time; these enterprises have not changed their legal form during this period. After taking into account the established criteria, evaluated sample of the business consists of 982 legal entities involving 550 companies ("CC") and 432 agricultural cooperatives ("C"). In case of the conducted analysis of assessment of the amount of the land tax, the number of enterprises in assessed group may vary due to the missing values of the indicators examined.

In particular, the article presents a theoretical view on the accounting and tax consideration of the agricultural land and land tax. Therefore, the selected provisions of the Act no. 431/2002 Coll. on Accounting as amended (hereinafter referred as "Act on Accounting") and related accounting regulations are to be taken into consideration. The provisions of the Slovak accounting laws on land are compared with the provisions of the International Financial Reporting Standards (hereinafter referred as "IFRS/IAS"). Further, the agricultural land and land tax are to be taken into account according to the Act no. 582/2004 Coll. on local taxes and fees for municipal waste and construction wastes as amended (hereinafter referred as the "Act on local taxes"). The land tax is to be treated as the source of income of the municipalities. Further, the land tax is also considered from the Slovak income tax perspective, i.e. the Act no. 595/2003 Coll. on Income Tax as amended.

The article examines the significance of the differences in the values of monitored indicators as the examined dependent variables, such as agricultural land acreage and the amount of land tax calculated per 1 hectare of agricultural land. Evaluated variables are assessed on the basis of independent variables according to the combinations of the factor level of year and enterprise using selected statistical methods. For the selected indicators, selective descriptive characteristics such as: point and interval estimation of mean standard error of the mean estimation and standard deviation are being calculated. Point estimation of the mean is carried out using the single value. Interval estimation uses the numerical interval covering the value of the examined variable with certain reliability. Point and interval estimation of mean $(95 \%$ confidence interval) of the evaluated variables in each group shall be recalculated according to the combinations of the level of factors of year and enterprise.

For testing the significance of differences of selected dependent variables, the analysis of variance for repeated measures (ANOVA repeated measures) with the year as one repeated measures factor (dependent samples) and enterprise between-groups factor (independent samples) appears to be the most suitable. To use of tests of significance, it is necessary to meet the assumption of normality (normal distribution of variables), the assumption of equality of variances and the condition of the covariant matrix's sphericity - equality of variances and covariances in covariant matrix for repeated measurements. Mauchly's Test of Sphericity is 
used to verify the covariant matrix's sphericity that is the condition for using of analysis of variance for repeated measures with more than two levels. If the condition of the covariant matrix's sphericity is not fulfilled, then the Type 1 error rate increases. Therefore, in such cases degrees of freedom for the F-test are corrected using Greenhouse Geisser and Huynh//Feldt corrections in order to achieve the declared level of significance. After the rejection of the global hypothesis, we are focusing on between which levels of factors or their combinations are the differences statistically significant. For this purpose, the multiple comparisons, namely the Tukey HSD test, will be used. It belongs to more conservative tests.

Null hypothesis assumes that within agricultural land there are no statistically significant differences neither among the studied years nor among the combinations of level of factors "year" and "enterprise". Concerning the amount of the land tax, null hypothesis assumes that there are no statistically significant differences neither among the studied years nor among the combinations of level of factors "year" and "enterprise" as well. This means that the acreage of agricultural land and the amount of the land tax are not dependent on the factor of year and the combination of the factors of year and enterprise.

The article uses standard scientific methods such as selection, analysis, comparison, synthesis and deduction, which are generally known and therefore are not deeply analysed. These methods form the basic methodological approach for drawing up the theoretical and application part of the article.

\section{Results and Discussion}

Acreage of agricultural land is an important indicator used for comparing the results achieved by the enterprises with primary agricultural production in the Slovak Republic, when the values of the indicators are generally converted per 1 hectare of agricultural land. Lands represent a significant part of the assets of the enterprises with primary agricultural production. Lands (i.e. agricultural land) are, in accordance with the accounting and tax legislation of the Slovak Republic, considered as tangible asset excluded from the depreciation.

According to the accounting legislation of the Slovak Republic, agricultural land belongs to longterm tangible asset, which is intended to be used for a period longer than one year, and can be a source of economic benefits (enterprise's financial revenues) for several years. Task of this type of the asset is to ensure and support the existing business activity of the agricultural enterprise. Agricultural lands cannot be depreciated, because it is not possible for them to determine the period of their useful life. Lands can be included also under long-term financial assets, if they are acquired for the purpose of imposition of free cash. Within the accountancy, land is charged to the property: to which the enterprise has a right of ownership or administration; if it is a state property and also in the case if the enterprise has not a right of ownership or administration; if it is a long-term intangible asset acquired under the contract according to which the right of ownership or administration is acquired by permission for the entry into Land Register, if the enterprise uses the immovable property until acquiring a right of ownership or administration. Method of agricultural land's valuation depends also on the way of its acquisition. It may be the acquisition cost or fair value in certain specific cases. In case of acquisition, the lands are initially valued at the date of accounting case and, consequently, may be valued within their reporting at the date on which the financial statement is prepared. As concerns immovable property acquired on the basis of contract with ownership transferred by approval of entry into land register and used by the buyer before ownership transfer, the date of accounting case implementation is the date of takeover of the immovable property by the buyer. Acquisition costs include the costs for which the land was purchased, including costs associated with its acquisition and including all reductions of the purchase price. The fair value shall mean the market value established by an appropriate valuation model. It can be also established by the expert report, if it is not possible to determine the fair value of the assets by the previous methods of valuation.

Except of the Slovak accounting legislation the consideration on agricultural land acquired for the purpose of long term business activities of the enterprise is covered also in IAS $16-$ Property, plant and equipment. According to IAS 16 - Property, plant and equipment land 
becomes a separate class of property, plant and equipment. The land has an unlimited useful life and therefore is not depreciated. Further, according to IAS 16 property, plant and equipment are tangible assets that: (i) are held for use in the production or supply of goods or services, for rental to others, or for administrative purpose; and (ii) are expected to be used during more than one period. For the purpose of land classification into the particular asset the principle of significance need to be taken into account as well as selected model valuation (acquisition costs or fair value) need to be applied for the whole class of reported asset. The accurate valuation of lands in financial statements depends on the initial valuation and properly selected valuation model. IAS 16 allows two options in valuation of lands in financial statements (i) model of acquisition costs and (ii) revaluation to fair value.

In respect to historic connection of the accounting and tax legislations, the particular issue in question is to be solved also from the tax perspective. According to the Slovak tax legislation lands are tangible assets excluded from the depreciation. In view of the above, it means that the lands are not depreciating even for tax purposes, and are reported within the acquisition costs. It can be concluded that the assessment of the land carrying out while valuating the property is closely linked to the accounting legislation of Slovak Republic.

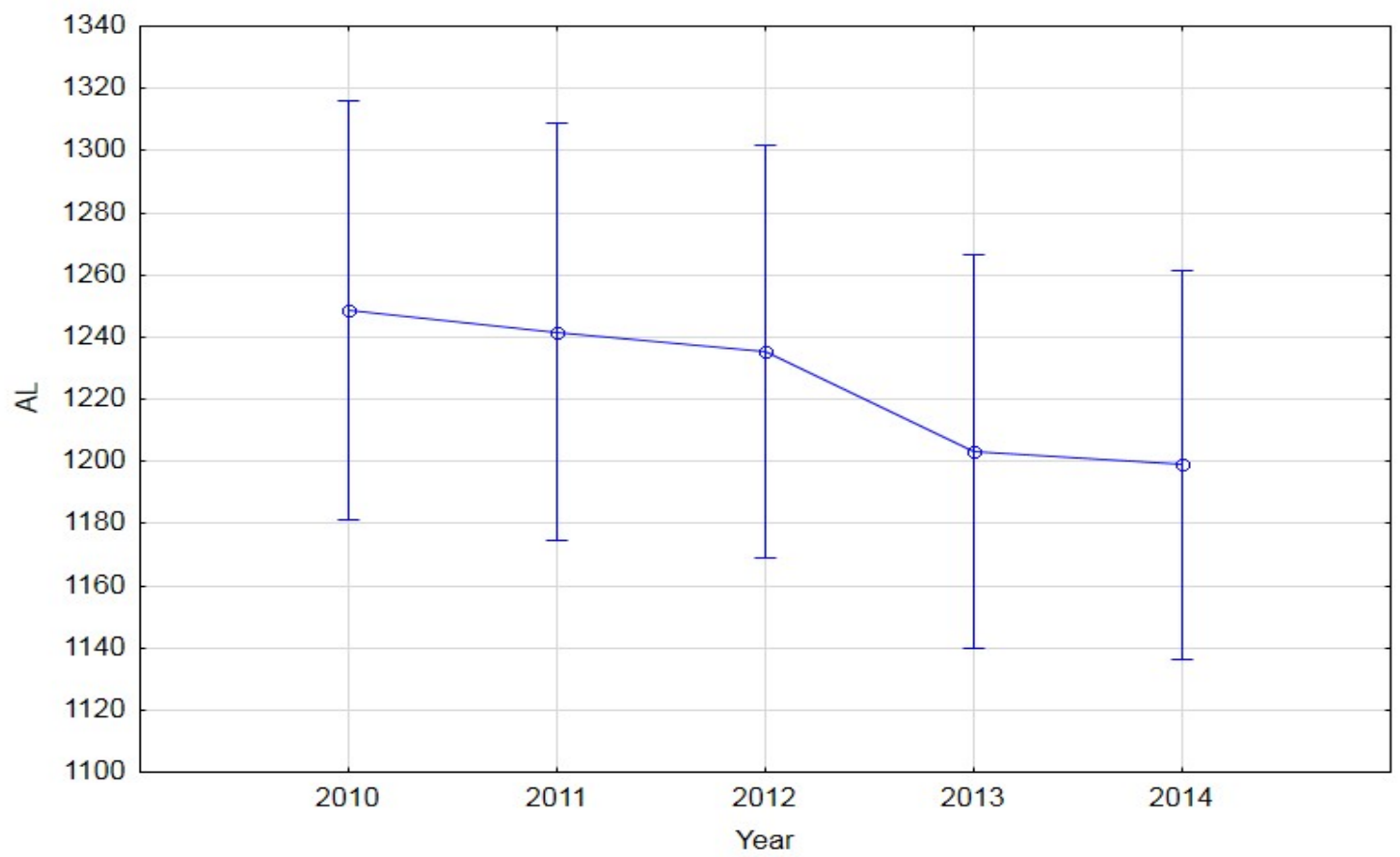

Fig 1. Mean and the confidence interval for the acreage of AL in hectares (2010-2014). Source: own calculation based on data from the Information Letters of the MARD SR

Calculation of selected descriptive characteristics and $95 \%$ of confidence intervals for selected indicators for evaluated group of enterprises was chosen for the presentation of results, specifically for Cs and CCs in the time frame 2010 - 2014. On the basis of the values obtained, it is possible to assess the evolution of the mean level of the acreage of agricultural land (AL) during the years examined in the selected group of businesses with primary agricultural production (Fig. 1).

In view of the value of the mean and $95 \%$ confidence interval for the assessment of the areas of agricultural land, a slightly declining trend was recorded for the evaluated group of enterprises. It can be concluded that the abovementioned corresponds with overall worldwide and Slovak trend of the decrease of the acreage of utilized agricultural land. All types of lands had a share on the overall decrease of the acreage of utilized agricultural land (Report on Agriculture and Food industry in the Slovak Republic, 2014). More significant decrease in the acreage of agricultural land during the reporting period has been recorded in 2013, when the mean acreage of agricultural land for a selected group of enterprises with $95 \%$ reliability ranged 
between 1, 114.794 and 1, 242.882 hectares. In 2012, the mean rage acreage of agricultural land with a 95\% confidence belonged to the interval between 1, 144.806 and 1,278.736 hectares. The analysis was conducted in the agricultural enterprises with primary production including Cs and CCs, since Cs and CCs have a dominant position among the legal entities producing on land in Slovakia (Kotulič and Adamišin, 2010). Cs compared to CCs were characterised by larger mean acreage of agricultural land and there is also a preponderance of this kind of property in Cs over its mean value in CCs. In 2014, the mean acreage of agricultural land in Cs was 1, 402.664 hectares (with 95\% reliability). In the same year, CCs showed lower mean value of agricultural land at a level of 995.224 hectares. Development of the agricultural land is characterized by faster decrease of its acreage in developed countries with a higher intensity of agricultural production and its increase in developing countries with predominantly extensive agricultural production (Report on Agriculture and Food Industry in the Slovak Republic, 2014).

Following the results of the selected descriptive characteristics of examined variables, the significance of differences of selected factors according to the combinations of the levels of "year" and "enterprise" has been tested. Based on the results of the Mauchly's Test of Sphericity $(\mathrm{W}=0.196$; Chi-square $=1595.396 ; \mathrm{df}=9 ; \mathrm{p}=0.0000)$, the presumption of validity was violated for the variable of acreage of agricultural land. Adjusted Univariate Tests for Repeated Measure are used for testing the differences. In the first three columns (Tab. 1), there are unadjusted results of the variance analysis and in the next columns the results are modified. The results are the same.

\begin{tabular}{|l|r|r|c|c|c|c|c|}
\hline \multirow{2}{*}{ Effect } & \multicolumn{7}{|c|}{ Adjusted Univariate Tests for repeated measure } \\
\cline { 2 - 8 } & $\begin{array}{l}\text { Degree of } \\
\text { Freedom }\end{array}$ & $(\mathrm{F})$ & $(\mathrm{p})$ & $\begin{array}{c}\mathrm{G}-\mathrm{G} \\
\text { Epsilon }\end{array}$ & $\begin{array}{c}\mathrm{G}-\mathrm{G} \\
\text { Adj. df1 }\end{array}$ & $\begin{array}{c}\text { G-G } \\
\text { Adj. df2 }\end{array}$ & $\begin{array}{c}\mathrm{G}-\mathrm{G} \\
\text { Adj. } \mathrm{p}\end{array}$ \\
\hline & 1 & 37.541 & 0.000000 & & & & \\
\hline Year & 4 & 15.89006 & 0.000000 & 0.592545 & 2.370181 & 2322.777 & 0.000000 \\
\hline Year * Company & 4 & 0.35905 & 0.837859 & 0.592545 & 2.370181 & 2322.777 & 0.734278 \\
\hline Error & 3920 & & & & & & \\
\hline
\end{tabular}

Tab 1. Adjusted Univariate Tests for repeated measure for assessment of agricultural land. Source: own calculation based on data from the Information Letters of the MARD SR

Two global hypotheses have been set up for the case of the dependent variable "acreage of agricultural land". Global hypothesis at the level of the factor of year assumes that there are not statistically significant differences in the acreage of agricultural land between examined years. It is rejected at the $0.1 \%$ significance level. We do not reject the global hypothesis at the level of the combinations of year and enterprise. This means that there is no statistically significant difference in the acreage of agricultural land between the combinations of the level of the factors of year and enterprise $(p=0.7343)$. In case of rejection of the global hypothesis, which claims that there is no statistically significant difference between examined years, the Tukey HSD Test shall be applied (Tab. 2). On its basis, there exist statistically significant differences in the acreage of agricultural land in individual years. Statistically significant differences between the years 2013/2014 and others years have been shown between two identified homogenous groups $(2013,2014)$ and $(2010,2011,2012)$.

\begin{tabular}{|c|c|c|c|c|}
\hline \multirow{2}{*}{ Cell No. } & \multicolumn{4}{|c|}{ Tukey HSD Test } \\
\cline { 2 - 5 } & Year & Mean & 1 & 2 \\
\hline 5 & AL 2014 & 1174.464 & & ${ }^{* * * *}$ \\
\hline 4 & AL 2013 & 1178.838 & & ${ }^{* * * *}$ \\
\hline 3 & AL 2012 & 1211.771 & ${ }^{* * * *}$ & \\
\hline 2 & AL 2011 & 1217.581 & ${ }^{* * * *}$ & \\
\hline 1 & AL 2010 & 1224.125 & ${ }^{* * * *}$ & \\
\hline
\end{tabular}

Tab 2. Tukey HSD Test for assessment of agricultural land. Source: own calculation based on data from the Information Letters of the MARD SR 
From the category of direct taxes, land tax has demonstrably the highest share on the tax burden of enterprises with primary agricultural production in the Slovak Republic. Its volume depends mainly on the acreage of agricultural land, as well as on the applicable tax rate.

Tax obligations relating to establishment and termination of the land tax are governed by the Act on local taxes, according to which the agricultural enterprise as an owner of the land is obliged to pay the land tax to the respective tax administrator (i.e. municipal authority) within whose territorial jurisdiction the immovable property is located. The Act also defines the method of land tax calculation for the territory of the Slovak Republic. The status as of January 1 of the taxable period is decisive for levying of tax. Taxable period is the same as the period of a calendar year.

For the purposes of the land tax, agricultural land is understood as a land identified in the land register as a potentially productive land, such as arable land, hop-fields, vineyards, orchards, gardens and permanent grasslands. In general, the tax base is given by the value of agricultural land without crops, which is determined by multiplying the area of the lands (in $\mathrm{m}^{2}$ ) by the value of the land for $1 \mathrm{~m}^{2}$. The value of the land is the figure expressing the quality and value of the production-ecological potential of agricultural land (agricultural land is divided into nine groups of Bonited Soil-Ecological Units).

The annual land tax rate is $0.25 \%$. By applying the generally binding regulation, tax administrator may either decrease or increase this rate according to the local conditions in the municipality, in a part thereof, or in a cadastral area for the respective taxable period. For the municipality as the administrator of the land tax, this tax is important revenue for its budget. The land tax is then calculated by multiplying the taxable amount by the annual land tax rate. Abovementioned analysis shows that the amount of the agricultural land tax is significantly affected by the soil bonity and its amount depends on the cadastral area.

A number of literary sources (Buday and Čičová, 2014; Schwarcz et al., 2013) state that agricultural land tax is one of the ways of determining the official price of agricultural land. In our opinion, this tax is not an official price of the land; it only determines the value of agricultural land for the purpose of paying the land tax. Land tax, as one of the local taxes, is considered to be a tax deductible expense (expenditure), i.e. an expense incurred in order to achieve, ensure and sustain the taxable income of the agricultural enterprise. For the taxpayer, land tax is a cost from its economic activities, which affects the overall result achieved by the agricultural enterprise with primary production.

Based on the results of selective descriptive characteristics can be concluded that from 2010 until 2014 there was a growing trend of the mean value of land tax calculated per hectare of agricultural land (LT in EUR per hectare of $A L$ ) within selected group of evaluated enterprises in Slovak Republic (Fig. 2). Development of this indicator mainly relates to the reported acreage of agricultural land in the enterprises.

The most significant increase in the amount of the land tax was reached in 2013, when the overall highest mean land tax value (per hectare of agricultural land) was recorded - it ranged in an interval of $18.13281-21.85671$ EUR with $95 \%$ confidence. In our opinion, it likely relates to increase of tax rates determined by municipalities. Compared to 2013, the amount of the land tax in 2014 was stagnant. The mean tax for Cs was at the level of 18.14337 EUR and at the level of 20.98943 EUR for CCs. As well as in the case of agricultural land's acreage and the amount of the land tax (here as a dependent variable), Mauchly's Test of Sphericity $(\mathrm{W}=0.214$; Chi-square $=1502.138 ; \mathrm{df}=9 ; \mathrm{p}=0.0000$ ) proved violation of the presumption of validity. In view of the above, Adjusted Univariate Tests for Repeated Measure shall apply to test the significance of differences of the selected factors (Tab. 3). 


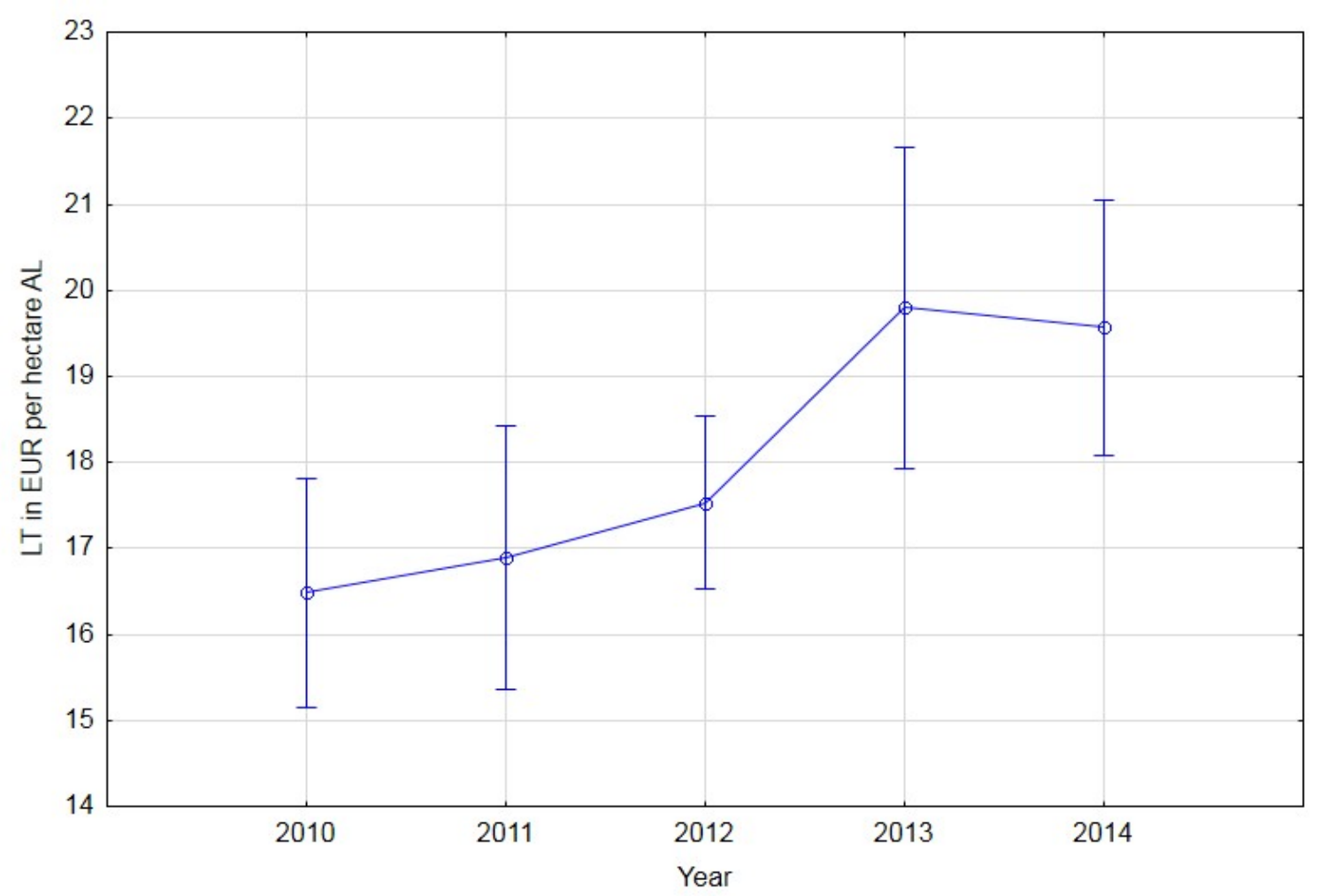

Fig 2. Mean and the confidence interval for the land tax (2010-2014). Source: own calculation based on data from the Information Letter of the MARD SR

\begin{tabular}{|l|r|c|c|c|c|c|c|}
\hline \multirow{2}{*}{ Effect } & \multicolumn{7}{|c|}{ Adjusted Univariate Tests for repeated measure } \\
\cline { 2 - 8 } & $\begin{array}{l}\text { Degree of } \\
\text { Freedom }\end{array}$ & $(F)$ & $(p)$ & $\begin{array}{c}\text { G-G } \\
\text { Epsilon }\end{array}$ & $\begin{array}{c}\text { G-G } \\
\text { Adj. df1 }\end{array}$ & $\begin{array}{c}\text { G-G } \\
\text { Adj. df2 }\end{array}$ & $\begin{array}{c}\text { G-G } \\
\text { Adj. } p\end{array}$ \\
\hline & 1 & 2.0407 & 0.153462 & & & & \\
\hline Year & 4 & 14.20369 & 0.000000 & 0.676175 & 2.704701 & 2639.788 & 0.000000 \\
\hline Year * Company & 4 & 2.11825 & 0.075924 & 0.676175 & 2.704701 & 2639.788 & 0.102618 \\
\hline Error & 3904 & & & & & & \\
\hline
\end{tabular}

Tab 3. Adjusted Univariate Tests for repeated measure for land tax. Source: own calculation based on data from the Information Letters of the MARD SR

Global hypotheses have been set up also for the variable of the land tax amount. Statistically significant difference in the variable $(p=0.1026)$ is not detected at the level of combinations of factors of year and enterprise and we do not reject the global hypothesis. At the level of the factor of year, a statistically significant difference in the variable $(p=0.0000)$ is found. The global hypothesis, which asserts that there is no statistically significant difference between the years, is rejected at the $0.1 \%$ significance level. Due to the refusal of one of the global hypotheses, Tukey HSD Test (Tab. 4), on the basis of which there exist significant differences in the amount of land tax per hectare of agricultural land in studied years, shall be applied.

\begin{tabular}{|c|c|c|c|c|}
\hline \multirow{2}{*}{ Cell No. } & Tukey HSD Test & Mean & 1 & 2 \\
\cline { 2 - 5 } & YT in EUR per hectare AL 2010 & 16.54865 & ${ }^{* * * *}$ & \\
\hline 1 & LT in EUR per hectare AL 2011 & 16.97618 & ${ }^{* * \star *}$ & \\
\hline 2 & LT in EUR per hectare AL 2012 & 17.56146 & ${ }^{* * * *}$ & \\
\hline 3 & LT in EUR per hectare AL 2014 & 19.73227 & & $*{ }^{* * * *}$ \\
\hline 5 & LT in EUR per hectare AL 2013 & 19.99476 & & $* * * *$ \\
\hline 4 & &
\end{tabular}

Tab 4. Tukey HSD Test for tax land. Source: own calculation based on data from the Information Letters of the MARD SR 
Statistically significant differences between the years 2013/2014 and others years have been shown between two identified homogenous groups $(2013,2014)$ and $(2010,2011,2012)$.

\section{Conclusion}

Based on the analysis and assessment carried out for the acreage of agricultural land and the amount of the land tax in selected group of enterprises with primary agricultural production in Slovak Republic we formulate the following conclusions:

- On the basis of a comparison of the Slovak accounting and EU legislation with tax legislation can be concluded the consistency of the formal and content definition of the terminology relating to agricultural land. For accounting purposes, agricultural land is considered to be a tangible asset excluded from the depreciation. This means that the agricultural enterprise does not charge the depreciation costs from the long-term tangible asset such as costs from operations. Tax assessment of the lands is characterised by its close connection to the accounting legislation;

- Amount of the land tax depends on the acreage and bonity of agricultural land as well as on the cadastral area, within which it is located. Land tax levied by the municipality represents the significant tax revenue for its budget that can be utilized to regional development. The land tax in question significantly affected by current effective tax rate, its volume depends on the local conditions and cadastral area. The land tax directly influence the income from operation activities of the particular enterprise;

- Based on the reported results of selective descriptive characteristics of indicators can be concluded that within the monitored period of years from 2010 until 2014 there was a decrease trend of the agricultural land while an average value of land tax calculated per hectare of agricultural land within the selected group of evaluated enterprises in Slovak Republic has increased;

- Results of the survey on significances of differences in the values of the dependent variables indicate that there are statistically significant differences in the acreage of agricultural land as well as in the volume of the land tax within the surveyed period. They were assessed on the basis of independent variables at the level of the factor of year. This means that examined variables depend on the specific years, in which their evaluation was carried out. Based on the abovementioned can be concluded that statistically significant differences between the years 2013/2014 and others years have been shown between two identified homogenous groups $(2013,2014)$ and $(2010,2011$, 2012). Combination of the levels of the factors of year and enterprise shows that there are no statistically significant differences neither in the acreage of agricultural land nor in the amount of land tax for the surveyed group of agricultural enterprises with primary production in surveyed period. This means that the variables do not depend neither on a combination of years surveyed nor on the enterprises assessed;

- In our view, business activities in the agriculture sector of the Slovak Republic can substantially improve regional development. It is recommended that the municipality such as regional authorities should determine useful effective tax rate that be essential for sustainability of particular region.

\section{Acknowledgement}

This work was supported by project "Common agricultural policy 2014-2020 and its impact to financial situation of agricultural enterprises in the Slovak Republic" No. 1/0912/14 of the Science Grant Agency of the Ministry of Education, Science, Research and Sport of the Slovak Republic and the Slovak Academy of Science. 
[1] Adamišin, P. \& Kotulič, R. (2010). Analýza ekonomickej výkonnosti subjektov hospodáriacich na pôde podla právnej formy (pp. 6-13). In Kotulič, R. \& Adamišin,P., eds., Prosperita pol'nohospodárskej výroby pre zabezpečenie trvaloudržatel'ného rozvoja regiónov. Zborník vedeckých prác z riešenia projektu VEGA č. 1/0403/09. Prešov: Prešovská univerzita

[2] Bandlerová, A., Schwarcz, P., Lazíková, J., Dirgasová, K. \& Schwarczová, L. (2015). The current issues of agricultural land market in Slovakia. Economica, 8(4), 71-76.

[3] Bielik, P. \& Turčeková, N. (2013). Podnikové hospodárstvo. Nitra: SPU.

[4] Buday, Š. \& Čičová, T. (2014). The transactions in the agricultural land market in Slovakia. Agricultural Economics - Czech, 60(10), 449-457.

[5] Cahill, C. (2001). Multifunctionality: towards an analytical framework. Tijdschrift voor Sociaalwetenschappelijk onderzoek in de Landbouw, 16(2), 59-71.

[6] Dale, P. \& Baldwin, R. (2000). Emerging Land Markets in Central and Eastern Europe (pp. 81-115). In Csaki, C. \& Lerman, Z., eds., Structural Change in the Farming Sectors of Central Eastern Europe. Warsaw: World Bank.

[7] Horská, E., Espolov, T. I., Gálová, J., Krasnodębski, A., Kornalska, E., Trela, W., Voronina, A. \& Singh, A. K. (2013). Sustainability in business and society: global challenges - local solutions. Kraków: Wydawnictwo Episteme.

[8] International Financial Reporting Standards. Part A. (2013). London: IFRS Foundation.

[9] Králiková, A., Ciaian, P. \& Pokrivčák, J. (2013). The value of agricultural landscape in Slovakia (pp. 336-340). In Proceeding from VIII. International Conference on Applied Business Research ICABR 2013. Brno: Mendel University in Brno.

[10] Land in Europe: Prices, Taxes and Use Patterns. EEA Technical Report No. 4/2010. (2010). Luxembourg: Office for Official Publications of the European Union. DOI: $10.2800 / 40386$.

[11] Lerman, Z., Csaki, C. \& Feder, G. (2004). Agriculture in Transition: Land Policies and Evolving Farm Structures in Post-Soviet Countries. Lanham, MD: Lexington Books.

[12] Loudjani, P. \& Devos, W. (2012). Land Parcel Information Systems for implementing the CAP. Supporting the CAP \& land management. [Retrieved 2015-10-01]. Retrieved from: http://ies-webarchive-ext.jrc.it/ies/our-activities/support-for-member-states/lpisiacs.html.

[13] Munk, M. (2011). Počítačová analýza dát. Nitra: UKF.

[14] Opatrenie MF SR č. 23054/2002-92, ktorým sa ustanovujú podrobnosti o postupoch účtovania a rámcovej účtovej osnove pre podnikatelov účtujúcich $v$ sústave podvojného účtovníctva v znení neskorších predpisov.

[15] Podhrázská, J., Vaishar, A., Toman, F., Knotek, J., Ševelová, M., Stonawská, K., Vasylchenko, A. \& Karásek, P. (2015). Evaluation of Land Consolidation Process by Rural Stakeholders. European Countryside, 7(3), 144-155. DOI: 10.1515/euco-2015-0010.

[16] Puzule, A. (2015). Assessment of direct taxation instruments. Journal of Social Sciences, 1(7), 147-163. DOI: 10.3844/jssp.2016.1.13.

[17] Schwarcz, P., Bandlerová, A. \& Schwarczová, L. (2013). Selected issues of the agricultural land market in the Slovak Republic. Journal of Central European Agriculture, 14(3), 11021115. DOI: 10.5513/JCEA01/14.3.1314.

[18] Sivák, R., Belanová, K. \& Jančovičová Bognárová, K. (2015). Financie podnikatel'skej sféry. Bratislava: SPRINT 2 s.r.o. 
[19] Správa o pol'nohospodárstve a potravinárstve v SR za rok 2013 (2014). Bratislava: Národné pol'nohospodárske a potravinárske centrum - VÚEPP.

[20] Správa o pol'nohospodárstve a potravinárstve v SR za rok 2014. Bratislava: Národné pol'nohospodárske a potravinárske centrum - VÚEPP.

[21] Váryová, I., Ferenczi Vaňová, A., Košovská, I. \& Krajčírová, R. (2015). Information tools of cost controlling in entities (pp. 502-509). In Agrarian perspectives XXIV. Praha: Czech University of Life Sciences.

[22] Zákon č. 220/2004 Z.z. o ochrane a využívaní pol'nohospodárskej pôdy a o zmene zákona č. 245/2003 Z.z. o integrovanej prevencii a kontrole znečist'ovania životného prostredia a o zmene a doplnení niektorých zákonov.

[23] Zákon č. 431/2002 Z.z. o účtovníctve v znení neskorších predpisov.

[24] Zákon č. 582/2004 Z.z. o miestnych daniach a miestnom poplatku za komunálne odpady a drobné stavebné odpady $\vee$ znení neskorších predpisov.

[25] Zákon č. 595/2003 Z.z. o dani z príjmov v znení neskorších predpisov. 